\title{
Narratives of Strength, Perseverance ANd RESILIENCE IN TRADITIONAL MARRIAGES (FOCUS ON SINDHI WOMEN)
}

\author{
Maya Khemlani David \\ Asia Europe Institute, University of Malaya, Malaysia \\ Shobha Mirchandani \\ MS Aspire Counselling Services, Kuala Lumpur, Malaysia \\ Maria von Stumm \\ Attorney, Kuala Lumpur, Malaysia
}

\begin{abstract}
Resilience is the ability and knowledge of a person on what he/she can do when he/ she falls and learns how to get up. The aim of this paper is to understand the experiences and perceptions of diaspora Sindhi Hindu women in arranged marriages and how they dealt with the many challenges they faced in their martial homes whether in India or in Malaysia. Strength based theory (Saleeby, 2013) and Agency Favouring framework (Williams, 2000) are used to demonstrate their strengths and agency. The data is obtained from the written narratives of 5 women who married Sindhi men. Writing Is a powerful weapon for reminiscing and describing lived experiences of life in arranged marriages. The writing had to be analyzed for the themes that emerged after the initial codes were generated.
\end{abstract}

Key words: Resilience, Traditional Marriages, Sindhis, women

\section{INTRODUCTION}

\section{A. The Sindhis}

The Hindu Sindhis have been a diasporic community even before they lost their homeland when the Indian subcontinent was partitioned in 1947. With the partitioning of the Indian subcontinent about 800,000 Hindu Sindhis fled their homeland Sind (today in Pakistan) and made their homes in India and in many parts of the world. Today, they are found in many different parts of the world but they still maintain social and business networks with fellow Sindhis. There is a high level of mobility with Sindhi men travelling for business and women travelling to meet family and friends in different parts of the world. The Sindhi community is a globally dispersed ethnic group holding a collective identity.

The community for the large part believes in arranged marriages with fellow Sindhis. Due to the social networking and many kinship relationships that exist globally it has become the norm for parents of Sindhis to find potential life partners for their children from different countries. More recently however many young Malaysian Sindhis, both men and women, are contracting exogamous marriages.

\section{B. Arranged Marriages}

The traditional arranged marriage is accompanied by huge dowries and life in joint families. In the past the joint families generally consisting of the groom's parents, unmarried siblings and at times, older married siblings, and their families. The new bride coming from a different country also entered an entire new family in the marital home. The phenomenon of arranged marriages from the perspective of the women will be analysed using the themes that emerge from their written narratives.

\section{Power Structure in the family}

The society is a patrilineal one and the father- in-law's rules hold sway. If he is no longer alive the eldest son's words are law. This does not mean the mother-in-law (MIL) is powerless. In fact, it is the MIL who dominates and wields 


\section{Yinternational Research Journa!}

p-ISSN 2202-2821 e-ISSN 1839-6518 (Australian ISSN Agency)

power in the joint family household. Respect must be given to the elders in the family. The major social structures that affect the lives of the women, as seen in their narratives, will be described.

Today the pattern of joint living in Sindhi homes has changed. Many one-time Sindhi daughter-in-law (DIL) in Malaysia who have become MILs say it is best that the newly married couple have their own home. This has generally resulted in two flats in one condominium or homes near to or next to each other.

\section{Methodology}

Much of the information required for this research is highly confidential as the requirement to recall life in the marital home is sensitive. The 5 respondents were asked to reflect on their past histories in their marital joint family homes. We thought the best way to obtain such data was to ask the respondents to reflect, reminisce and write their own narratives. As it is not easy to obtain such private information selected respondents were asked by an intermediary who knew them well to narrate their life's experiences in arranged marriages in joint families. They were informed that they would remain anonymous even to the researcher. Therefore, in this research pseudonyms are used to maintain confidentiality. Four of the ladies were in their late fifties and one in her late thirties. Two were in India and 3 in Malaysia.

\section{Analysis}

The analysis is qualitative. Pavlenko's (2007) study recommended content and thematic analysis as an effective approach in autobiographical narratives. Consequently, thematic analysis was used to examine the narratives to identify patterns across the narratives and develop themes of resilience.

The narratives were read repeatedly to familiarise us with the data to generate initial codes and search for themes that caused conflicts and the strength and agency of the women in these marriages.

The themes that caused conflicts were the power that the parents-in-law, especially the MIL wielded over the DIL; the non-interference/indifferent/missing husband and the financial and emotional dependence of the new brides. These will be described and extracts from the narratives are provided.

\section{A. Strength based theory and Agency Favouring Framework}

A strength-based approach recognises the resilience of individuals and focusses on perseverance, determination and capabilities. The strengths perspective (Saleeby, 2013) is an empowerment-based perspective used in this paper which focusses on the women in arranged marriages. Strengths may be harnessed for resilience giving the women the agency to contest the challenging issues they faced. How the women subjects in this research have strengths and exercised choice and agency to empower themselves will be analysed from their own narratives.

\section{Findings}

First the themes causing conflict will be discussed.

\section{A. Themes causing conflict}

\section{Role of the new bride and the MIL}

The new bride was to serve not only the husband but all members of his household in the joint family she found herself in. She did not have any autonomy due to authoritative MILs. The MILs controlled the behaviour of the DILs including the clothes she had to wear, the make-up and jewellery she wore, the friends she could have, the times she could visit her parents, the tools/ equipment she used for washing clothes and cooking etc. For instance, one of the women was directed to manually wash the clothes even though there was a washing machine in the house, another was ordered to start a charcoal fire for tea every morning even though there was a gas stove in the house and another was ordered to go on all fours and brush the porch by hand even though they had a vacuum cleaner. Yet another DIL was ordered to cook for guests even though she was pregnant and had had a recent fall she still had to continue with the preparation of the food, with no concern shown by the MIL.

Generally, the women had little independence in their marital homes, their movements were restricted, their phone calls listened to, and even their cupboards and drawers inspected. One DIL said that her MIL criticised her to their common friends in her presence. DILs were also not expected to work outside the home or even continue their education even if such promises had been made prior to the marriage. These young women were powerless and everything they did or wanted to do had to be approved by the MIL. In short, numerous restrictions were imposed on the new brides.

Some MILs were according to one respondent "manipulative." ME gave an example of when she wanted to meet her friend, her MIL pretended to be sick and complained to her husband that his wife was always going out and not looking after her or the house.

The emotional and financial dependence of the women was not helped by the fact that a working DIL was seen to bring shame to the family. Moreover, education after marriage was not favoured as the role of the women was seen as one who stayed and worked within the home. 


\section{Yinternational Research Journa!}

p-ISSN 2202-2821 e-ISSN 1839-6518 (Australian ISSN Agency)

\section{Husbands}

In arranged marriages, apart from the financial standing of the groom to be, nothing much is known of the personality and character of the husband to be. The marriages of all 5 subjects, it appears were not fulfilling and even a period of courtship, even after the marriage date was fixed, was discouraged.

Men were expected to obey their parents and complied with their mothers' wishes regarding their wives. The husbands were busy, seldom home, continuously travelling and working and when home tended to spend much time with their parents and did not contest the views of the elders over their wives. Some even physically and verbally abused their wives and left to them the care of the children.

LEM reported that she never received birthday or any other card from her husband and when her friends informed her that they had received such cards she jokingly informed them that for her husband every day was a birthday. He did not accompany her for any party, so she accompanied her MIL to these functions. She did not feel loved and he was physically and verbally abusive.

As for LA's husband she found he had a mistress and he was also physically abusive. One time when her MIL complained to her son that she was disrespectful she says, "he almost dragged me out of the home." LA stopped reporting any grievances she had about her MIL to her husband because "If I tell anything to my husband the quarrel becomes bigger." In short, some husbands tended to listen to their mothers and a man caught between a mother and wife once told his mother, "You chose my wife, if you don't like her send her back."

SHA said her husband was constantly travelling and the times he was home he tended to spend more time with his parents, and she was practically a single mother to her children for many years. "He doesn't understand me or my feelings", she says. She says she received "no support" from her husband and they "led separate lives".

ME's husband was deeply immersed in his almost bankrupt business and only visited her in her maternal home where she had gone for the delivery of her first born, three months after the delivery of her first child. He was obsessed with money and in maintaining the family business.

\section{B. Strength and Agency}

We now move on to discuss how the women, through their narratives, show their strengths and their agency to contest such restrictions and empower themselves.
Vol. 10 No. 022020

82801002202008

\section{Financial Independence: Getting involved in the Family business and gaining respect}

Although the patrilineal power structure within Sindhi families determined the extent a woman could pursue her career four of the five women did not accept this with passivity. MO for instance, was taken aback when informed by her father-in-law that she could not return to work in her father's family business. She gently reminded him of the promise made prior to the arranged marriage whereupon he agreed but with many conditions. She could do this after staying home for a month and then doing all the cleaning and cooking duties before going to work and resuming the work in the home on returning from the family business. She had no choice but to accept this condition sometimes at the expense of her physical well being.

Over time, she used the monthly income she received from her natal family business for expenses and debts incurred by her in-laws. With her financial contribution their attitude to her changed considerably when they saw her willingness to help financially even to the point of selling her jewellery to clear their debts.

Another woman, ME, an educated woman, with two degrees, was patient and waited till the children started school then when the family business hit a financial problem, she persuaded her FIL that she could help in the family business when the children were in school. On joining the family business, she was extremely successful in making the most sales and they then started to rely on her by leaving the shop for an afternoon siesta whenever she was in the shop. Her husband too started running other errands leaving her to mind the shop. She gained respect from the family as was now seen as an enterprising businesswoman.

Yet another woman who had an accounting degree, LEM was initially invited to do the family accounts by her FIL despite her MIL's objections and over time, quietly pursued some online courses and after some years a job outside the family business which gave her own personal income and financial independence. LEM patiently tolerated her life "in jail" but now the children are in universities she now, as a financially independent woman, fights for her rights and "Now he is afraid of me when once I was afraid of him."

Another woman, LA also bided her time during the difficult times and reported that she became financially independent, though lonely, when her husband suddenly died but now "she could live for herself. “

\section{Patience}

The strength is seen in their patience. LEM said she had to be patient and bear all the insults and felt 'she was in a prison,' as 


\section{Yinternational Research Journal}

p-ISSN 2202-2821 e-ISSN 1839-6518 (Australian ISSN Agency)

she was not given permission to do anything she wanted. She had to be patient as she' had two younger unmarried sisters and she knew if she returned to her natal home it would adversely affect their chances of getting a marriage partner. LEM therefore patiently waited till her children were in university whilst educating herself and becoming a professional before over time, asserting herself to her husband and even at one time after the death of her in-laws, demanding that her husband leave the martial home.

LA responded to the idea of another woman in her husband's life by dressing well and initially retaliating by flirting. But, like her mother, she like some of the other women who also had witnessed their mothers suffering in silence, she too suffered in silence for a Long time. LA after suffering for several years was "saved" by the death of her husband and her financial independence arising from his sudden demise.

MO made the decision not to have a child for seven years until her relationship with her husband improved after the sudden death of his father on whom he was very dependent. MO reports that after her FIL died, her husband who had shared much with his father now started sharing his feelings with her. Where for seven years she had decided not to have a child and bring it up in a loveless household she is now thinking that perhaps it is time to have a child.

SHA took refuge in prayers and friends she met at religious gatherings to sustain a "dead relationship" as she could not forgive her husband who had for a long time not been around and who did not support her emotionally, though he gave money for the children.

ME, after several years of being a homemaker in a joint family, focussed on earning money and becoming an astute businesswoman as she was not getting the attention and love she craved from her husband. Over time she says, she became like him "just focussing on making money".

Even with their domineering MILs the women initially and for a long time remained patient. Four of the five women mentioned in their narratives that their own mothers had remained silent despite domineering MILs and straying and non-attentive spouses. They had witnessed all these scenarios in their natal homes. They, therefore, initially remembered the responses of their mothers and used the strategy of remaining silent in the face of the demands made of them and the limitations imposed on them. They said they had no optionthey could not return to their natal homes as this was seen as bringing shame to the family. In addition, they were financially dependent on their spouses and in- laws.

These women had to be patient for a long time. At times they had to be patient till there was a death in the family. With the
Vol. 10 No. 022020

82801002202008

death of her FIL, MO's MIL is now dependent on her when she needs to go to the doctor as her own daughter lives in another town. Similarly, when ME's FIL died the MIL became dependent on ME. LA suffered in silence she says, like her mother did, until her husband suddenly passed on and her MIL then became dependent on her. The strengths of these women appear to being patient and slowly in their own way, in their own time, dealing with domineering MILs and with abusive, straying, money-minded, and over-filial sons.

\section{Agency: Strategies used}

A number of strategies were used by the women while remaining patient. These strategies show their agency.

\section{Negotiation}

For many of the women the dress code was prescribed by the MILs. ME used to wear western dresses in her natal home but was told by the MIL to dress and wear a sari when her husband returned from work. She says she was 6 months pregnant and it was uncomfortable to do this in the hot weather. She negotiated with this expectation and compromised by wearing Punjabi suits. Women thus have the agency through gentle persuasive talk to come to an agreeable compromise.

MO also negotiated with her FIL and agreed to do all the housework before and after returning from work if the FIL permitted her to work.

When the women noted that the in-laws were not happy for them to make friends with outsiders, they negotiated by making acceptable friendships with those, who like them, attended prayer or satsung sessions. Their in-laws accepted such social/ religious activities. SHA has "learnt to control her anger through satsung" (prayer meetings). Making and meeting friends at these prayer sessions has helped her "gain confidence in herself and now she is an independent and strong woman," she says.

\section{Final straw and agency}

The patience of the respondents was tested and it was at such times that agency comes to the fore. One woman, SHA reported that it was only when her mother was insulted that she started answering back. SHA remembers that when she was 50 years old her MIL complained to her mother "take your daughter back, she is good for nothing." It is these critical incidents that act as a catalyst to give strength and agency and it is then that there is resistance to traditions like not responding to MILs. Soon after this incident, SHA after many years of living together in one house, also insisted on having her own flat and suggesting that the MIL could have the flat next door. 
ME lived with both in-laws until she was told that she had not contributed capital to the family business. She was so upset about this dishonesty that she raised her voice and there was a huge quarrel. Soon after, her FIL died, and her MIL became dependent on her.

LEM reports that although her mother had recently died her MIL insisted on holding a party for her three- year old daughter. But at the same time she stated "You don't hold a party when I die." LEM's MIL controlled her friendships and phone calls and even went through her cupboards. There came a point when LEM decided to leave the house, and this gave a shock to her MIL as she had to face the highly networked members of her community. MIL's control over LEM was reduced after this incident.

The women, like their mothers, have learned to be patient and silently bear the grievances and tolerate their lack of independence. Perseverance has been their strength and has paid off over time sometimes due to the demise of the spouse or the in-laws. However, critical incidents like accusations they faced gave them the inner strength and the agency to either run away from the family home as LEM did or insist on their own home as SHA did or not to remain silent in the face of betrayal of trust and to answer back as ME did. For one woman having faith in God by attending satsung gave her the strength to empower herself and stand for her rights.

\section{Conclusion}

This study describes the challenges that five Sindhi Hindu brides faced in their marital homes in Malaysia and India. The social structure incorporating joint family households, the busy and filial sons they had married and the power that the MIL wielded have been described. These stories of their lives have been provided by the women themselves. Strength based and agency favouring approaches are noted in the life stories narrated. Their strengths mainly of perseverance and patience helped them at times to negotiate and at times resist and rebel against the power structures. They possessed the agency after tolerating hardships for a considerable period of time to weather the storms, surmount the challenges and lead their own lives. It must be emphasised that the sample is small and that generalisations cannot be made.

\section{REFERENCES}

[1]. Pavlenko, A. (2007) Autobiographical narratives as Data in Applied Linguistics. Applied Linguistics 28:2,163-188.

[2]. Saleeby, D. (Ed). (2013). Strength perspective in social work practice (6th ed.) Boston, M. A. Allyn and Bacon

[3]. Williams, M. (2000) Virtually criminal discourse, deviance and anxiety within virtual communities. International Review of Law, Computers and technology 14, 11-24.

[4]. David, M. K., Channa, L. A. ., Manan, S. A. and Dumanig, F. (2020) "Language Shift and Ethnic Identity: Focus on Malaysian Sindhis", IARS' International Research Journal. Vic. Australia, 10(1). doi: 10.51611/curie.v10i1.92. 